\title{
An investigative study of seismic landslide hazards
}

\author{
Nirmala Vasudevan ${ }^{1,2}$, Sreevalsa Kolathayar ${ }^{3}$, Aadityan Sridharan², Kaushik Ramanathan ${ }^{3}$ \\ ${ }^{1}$ Amrita Center for Wireless Networks and Applications, Amrita School of Engineering, Amritapuri \\ ${ }^{2}$ Department of Physics, Amrita School of Arts \& Sciences, Amritapuri \\ ${ }^{3}$ Department of Civil Engineering, Amrita School of Engineering, Coimbatore \\ Amrita Vishwa Vidyapeetham, Amrita University, India \\ nirmalav@am.amrita.edu, k_sreevalsa@cb.amrita.edu, aadityan1993@gmail.com, kaushikramanathan@am.amrita.edu
}

\begin{abstract}
A decade ago, in September 2006, the European Commission sanctioned Amrita University, Kerala, to design, develop, and deploy a wireless sensor network-based landslide monitoring system. The deployment was completed in June 2009, at the Anthoniar Colony Landslide in Munnar, Kerala, and the system has been in successful operation since then. Recently, the Government of India commissioned Amrita University to deploy a similar landslide monitoring system in the Himalayas. We selected the Chandmari Landslide in Gangtok City, Sikkim, as our deployment site. The deployment has been phased in two stages. The first stage, completed in June 2015, was a pilot deployment in which a $33.5 \mathrm{~m}$ deep borehole was drilled into rock, piezometers and inclinometers were installed, and rock samples were extracted and analyzed. Soil samples were extracted from elsewhere on the hill and tested. In the second stage, we will instrument other areas of Chandmari Hill, so that the entire region can be adequately monitored. Chandmari lies in a seismically active zone and has experienced earthquake-induced landslides in the past. In this paper, we present a thorough analysis, considering linear and gridded seismicity models and three sets of ground motion prediction equations, and estimate seismic hazard at Chandmari. In addition, we report, in detail, the results of the Chandmari soil and rock tests. We then describe a method that uses these soil and rock test results and seismic hazard analyses to estimate seismic landslide hazard at the site.
\end{abstract}

Keywords-Chandmari; Sikkim; Himalaya; landslide; seismic landslide hazard; earthquake; soil; rock; geotechnical characterization; rock and debris slide

\section{INTRODUCTION}

A landslide is the movement of a mass of rock, debris, or earth down a slope or a cliff. Landslides can be extremely destructive, causing extensive damage to property and significant loss of human life. Petley [1], [2] recorded over 80,000 landslide fatalities during the seven-year period from 2004 - 2010. More recently, Kirschbaum [3] reported over 25,000 fatalities caused by 6,790 landslides during the nineyear period from 2007 - 2015, and in the first five-and-a-half months of this year, from 1 January - 17 May 2016, Petley [4] documented 114 landslides and 620 fatalities.

Landslides are commonly classified [5], [6] using two nouns: the first noun describes the type of material (rock, debris, or earth) present before the onset of the slide, and the second noun describes the movement (fall, topple, slide, flow, or spread) of the material. Debris is coarse material in which $20 \%$ or more of the particles are $2 \mathrm{~mm}$ or larger in size; earth is comparatively finer material in which $80 \%$ or more of the particles are smaller than $2 \mathrm{~mm}$. If the landslide is complex, and the nature of the material or its movement changes as the landslide progresses, several classifiers are used to describe the event, e.g., a rock fall-debris slide. Both debris slides and rock slides-debris slides, also called rock and debris slides, have been recorded at Chandmari ( $27^{\circ} 20^{\prime}$ $\mathrm{N}, 88^{\circ} 37^{\prime} \mathrm{E}$ ). In addition to landslides, ground subsidence is a common phenomenon at Chandmari.

\section{BACKGROUND}

\section{A. The Anthoniar Colony Deployment}

We, a team of researchers from Amrita University, developed and deployed a wireless sensor network to monitor the Anthoniar Colony Landslide in Munnar, Kerala [7], [8]. About 150 sensors were installed at different depths ranging from 0 to over $20 \mathrm{~m}$. The sensors included:

- Piezometers to measure pore water pressure

- Dielectric moisture sensors to measure the moisture content of the soil

- Inclinometers to detect slope movement

- Strain gauges, as inexpensive alternatives to inclinometers, and

- Geophones to record ground vibrations

A weather station was also installed to record rainfall intensity and duration.

The sensors were connected to motes, via data acquisition (DAQ) boards, to form wireless sensor nodes. The wireless sensor nodes transmit sensor data from the deployment site to our University Campus, over an aerial distance of $130 \mathrm{~km}$. The data are transmitted sequentially through an IEEE 802.15.4-based network (ZigBee) of relay nodes, a Wi-Fi local area wireless network, and a VSAT (satellite) network, each network interfaced with the next via a gateway. In the absence of satellite connectivity, sensor data are transmitted either via the cellular network, or a broadband connection. Data received at the University Campus are streamed live to the Internet to a passwordprotected website. 
The system employs a three-level warning strategy. At the first level, when the sensor data cross certain initial thresholds, the system automatically sends messages to the researchers alerting them to monitor the data. At the second level, if data from multiple sensors show anomalies and the researchers feel that there is cause for concern, they notify the local officials. At the third level, if a landslide seems imminent, the local residents will be evacuated. Every monsoon season, the initial alert is sent to the team members, and on two occasions - the 2009 and the 2011 monsoons second level warnings were issued.

The project was initiated in September 2006, the deployment was completed in June 2009, and the system has been in operation since then.

\section{B. The Chandmari Deployment}

Based on the success of the Anthoniar Colony Landslide Monitoring System, the Government of India recently commissioned Amrita University to deploy a similar system in the Himalayas. We visited around thirty landslide sites in Uttarakhand, Mizoram, and Sikkim states, and selected the Chandmari Landslide in Gangtok City, Sikkim, as our deployment site on the basis of the following considerations: population affected by the landslide, the probability of future landslide activity, network connectivity especially during the monsoons, accessibility by road, and availability of water and electricity needed for the deployment.

The deployment is being phased in two stages. The first stage, completed in June 2015, was a pilot deployment in which a $33.5 \mathrm{~m}$ deep borehole was drilled into rock, piezometers and inclinometers were installed, and rock samples were extracted and analyzed. Additionally, soil samples were extracted from elsewhere on the hill and tested. In the second stage, we will similarly instrument several other areas of Chandmari Hill, so that the entire region can be adequately monitored.

\section{GEOLOGY}

Gangtok lies in the Inner Himalayas, and its elevation ranges from $880 \mathrm{~m}$ to $2,350 \mathrm{~m}$ above mean sea level [9]. Gangtok is bounded by two rivers - the Rorochu on the east, and the Ranikhola on the west. Chandmari Hill lies in northeast Gangtok; the height of the hill is about 2,020 m, while its slope ranges from approximately $15^{\circ}-55^{\circ}$.

Gangtok lies close to the Main Central Thrust MCT-2. The MCT-2 separates two groups of rocks, with the amphibolite-grade Paro-Lingtse Formation thrusting southward over the lower greenschist-grade Daling Group of rocks [10]. The Paro Formation consists of staurolite-garnetmuscovite-biotite-bearing paragneisses, interfoliated with quartzites, while the Lingtse Formation consists of biotitebearing orthogneisses with prominent feldspar augen. The Daling Group consists of slates, phyllites, and schists, intercalated with quartzites.

At Chandmari Hill, Paro gneisses are interbedded with mica-schists that are weathered to fine sand-sized material. The thickness of the soil cover varies; at certain locations, the soil cover is non-existent, while at other locations it is reported to be over $20 \mathrm{~m}$ [11].

Gangtok receives an average rainfall of approximately 3,500 mm every year, with maximum rain during the months of June and July. Sikkim State lies in a seismically active region, and several strike-slip and thrust faults, such as the Main Boundary Thrust (MBT) and the Main Central Thrust (MCT) zone, pass through the state. Gangtok City and Chandmari Hill have experienced both rainfall-triggered and earthquake-induced landslides.

The earthquake-induced slides happened in the wake of major earthquakes, such as the $6.9 \mathrm{M}_{\mathrm{W}}$ earthquake that occurred at the Sikkim-Nepal Border on 18 September 2011.

\section{FIELD AND LABORATORY INVESTIGATIONS}

\section{A. Soil Tests}

We extracted both disturbed and undisturbed soil samples from depths of approximately $0.6 \mathrm{~m}$ from two locations on Chandmari Hill. Various geotechnical tests were performed in accordance with the Indian Standard. Table I and Fig. $1-3$ present the results of the soil tests, as well as pertinent information about the tests.

\section{B. Lithology}

A $33.5 \mathrm{~m}$ NX-borehole was drilled in the upper region of Chandmari Hill (borehole coordinates: 88 26' 50" E, $27^{\circ}$ 20 ' 23" N, and elevation: 1,865 m). Except for a negligible amount of topsoil (less than $0.5 \mathrm{~kg}$ ), the borehole yielded only rock samples, with high core recovery. Garnetiferous muscovite-biotite gneiss was obtained; most of the rock samples were medium-to-coarse grained, but some small rock masses were fine-grained and had lesser mica. The gneissic rock was in different stages of weathering; and unweathered rock, slightly weathered/altered rock, and weathered and brecciated rock fragments, were all extracted from the borehole. Rock that was weathered to uniform fine sand-grain size (most likely weathered mica-schist) was obtained from depths of $3.5-5.0 \mathrm{~m}, 6.0-9.0 \mathrm{~m}$, and 14.36 $-15.0 \mathrm{~m}$. The lithologic log is depicted in Fig. 4, while the bore log is presented in Table II.

Abbreviations used in Table I:

$e$ : Void ratio

$a_{v} \times 10^{-4}$ : Coefficient of compressibility, $\mathrm{m}^{2} / \mathrm{kN}$

$m_{v} \times 10^{-4}$ : Coefficient of volume change, $\mathrm{m}^{2} / \mathrm{kN}$

$C_{v} \times 10^{-3}$ : Coefficient of consolidation, $\mathrm{m}^{2} / \mathrm{s}$

$k \times 10^{-5}:$ Hydraulic permeability, m/s [12]

U: Undisturbed sample

D: Disturbed sample

R: Reconstituted sample, with bulk density and moisture content matching field conditions

O: Oven dried sample, with dry density the same as in situ dry density 
TABLE I. SOIL TESTS PERFORMED AS PER THE INDIAN STANDARD

\begin{tabular}{|c|c|c|c|c|c|c|c|c|c|c|c|}
\hline & \multicolumn{6}{|c|}{ Geotechnical test } & \multicolumn{2}{|c|}{$\begin{array}{l}\text { Location } 1 \text {, in the } \\
\text { Forest, south of the } \\
\text { workshop }\end{array}$} & \multicolumn{3}{|c|}{$\begin{array}{l}\text { Location 2, near } \\
\text { Enchey playground }\end{array}$} \\
\hline $\mathrm{U}$ & \multicolumn{6}{|c|}{$\begin{array}{l}\text { Bulk density }\left(\mathrm{kg} / \mathrm{m}^{3}\right) \text {, measured at the time of sample } \\
\text { extraction }\end{array}$} & \multicolumn{2}{|c|}{1,31} & \multicolumn{3}{|r|}{1,450} \\
\hline $\mathrm{U}$ & \multicolumn{6}{|c|}{$\begin{array}{l}\text { Natural moisture content (\%), using the oven drying } \\
\text { method }\end{array}$} & \multicolumn{2}{|c|}{21.} & \multicolumn{3}{|r|}{12.7} \\
\hline $\mathrm{D}$ & \multicolumn{6}{|c|}{$\begin{array}{l}\text { Grain size (gravel, sand, silt, clay \%), from wet sieve } \\
\text { and hydrometer analysis }\end{array}$} & \multicolumn{2}{|c|}{$2,58,33$} & & & \\
\hline $\mathrm{D}$ & \multicolumn{6}{|c|}{ Liquid limit, using the Casagrande apparatus } & \multicolumn{2}{|c|}{$\begin{array}{r}\text { Could not be } \\
\text { determined }\end{array}$} & \multicolumn{3}{|c|}{$\begin{array}{r}\text { Could not be } \\
\text { determined }\end{array}$} \\
\hline $\mathrm{D}$ & \multicolumn{6}{|l|}{ Plastic limit } & \multicolumn{2}{|c|}{$\begin{array}{r}\text { Could not be } \\
\text { determined }\end{array}$} & & \multicolumn{2}{|c|}{$\begin{array}{r}\text { Could not be } \\
\text { determined }\end{array}$} \\
\hline & \multicolumn{6}{|c|}{ Plasticity index } & \multicolumn{2}{|c|}{ Non-plasti } & & \multicolumn{2}{|c|}{ Non-plastic } \\
\hline $\mathrm{D}$ & \multicolumn{6}{|c|}{ Specific gravity, using the density bottle method } & \multicolumn{5}{|c|}{2.46} \\
\hline \multicolumn{12}{|c|}{ Unconsolidated undrained (UU) direct shear test, rate of shear: $1.25 \mathrm{~mm} / \mathrm{min}$} \\
\hline $\mathrm{O}$ & \multicolumn{6}{|c|}{ Cohesion $(\mathrm{Pa})$} & \multicolumn{3}{|c|}{22,000} & & 730 \\
\hline $\mathrm{O}$ & Angle of int & al fric & (degre & & & & & & & & 44 \\
\hline $\mathrm{Co}$ & olidated drai & (CD) & $\mathrm{tsh}$ & st, ra & ge & $125 \mathrm{~m}$ & $\min$ & & & & \\
\hline $\mathrm{R}$ & Cohesion (F & & & & & & & & & & 2,770 \\
\hline $\mathrm{R}$ & Angle of int & al fric & (degre & & & & & & & & 36 \\
\hline $\mathrm{R}$ & Compressio & $\operatorname{ndex} C$ & & & & & & & & & 0.35 \\
\hline Hy & raulic perm & ility a & onso & ion p & nete & using & pedom & & & & \\
\hline & Load & & Loc & n $1, F$ & & & & ation & ear $P$ & groun & \\
\hline & & $e$ & $a_{v}$ & $m_{v}$ & $C_{v}$ & $k$ & $e$ & $a_{v}$ & $m_{v}$ & $C_{v}$ & $k$ \\
\hline $\mathrm{U}$ & 1,000 & - & - & - & - & 2.44 & - & - & - & - & - \\
\hline $\mathrm{R}$ & 500 & 1.16 & - & - & - & - & 0.93 & - & - & - & - \\
\hline $\mathrm{R}$ & 1,000 & 1.16 & - & - & - & 1.82 & 0.93 & 3.0 & 1.5 & 7.4 & 1.11 \\
\hline $\mathrm{R}$ & 2,000 & 1.15 & - & 6.1 & 3.0 & 1.78 & 0.93 & 5.3 & 2.8 & 3.7 & 0.99 \\
\hline $\mathrm{R}$ & 3,000 & 1.15 & 4.8 & 2.2 & 7.1 & 1.56 & 0.92 & 5.9 & 3.1 & 3.2 & 0.96 \\
\hline $\mathrm{R}$ & 4,000 & 1.14 & 7.5 & 3.5 & 4.4 & 1.53 & 0.91 & 6.6 & 3.4 & 2.7 & 0.92 \\
\hline $\mathrm{R}$ & 5,000 & 1.11 & - & - & 1.1 & 1.46 & 0.90 & - & 5.6 & 1.6 & 0.90 \\
\hline $\mathrm{R}$ & 6,000 & 1.11 & 1.5 & - & - & 1.33 & 0.90 & - & - & - & 0.89 \\
\hline $\mathrm{R}$ & 7,000 & 1.10 & 4.6 & 2.2 & 5.9 & 1.26 & 0.90 & 3.5 & 1.9 & 4.8 & 0.88 \\
\hline $\mathrm{R}$ & 8,000 & 1.10 & 4.6 & 2.2 & 5.6 & 1.19 & 0.90 & 3.9 & 2.1 & 4.3 & 0.87 \\
\hline $\mathrm{R}$ & 9,000 & 1.10 & 5.0 & 2.4 & 4.9 & 1.16 & 0.89 & 3.6 & 1.9 & 4.5 & 0.85 \\
\hline $\mathrm{R}$ & 10,000 & 1.09 & 6.6 & 3.1 & 3.7 & 1.15 & 0.88 & - & 6.8 & 1.3 & 0.84 \\
\hline $\mathrm{R}$ & 15,000 & 1.06 & 6.5 & 3.1 & 3.6 & 1.12 & 0.79 & - & 9.6 & 0.8 & 0.73 \\
\hline $\mathrm{R}$ & 20,000 & 0.82 & - & - & - & 0.75 & 0.76 & 7.2 & 4.1 & 1.7 & 0.67 \\
\hline $\mathrm{R}$ & 40,000 & 0.65 & 8.8 & 5.4 & - & 0.49 & 0.66 & 4.9 & 2.9 & 1.8 & 0.52 \\
\hline $\mathrm{R}$ & 10,000 & 0.66 & - & - & - & - & 0.67 & - & - & - & - \\
\hline $\mathrm{R}$ & 2,500 & 0.67 & 1.5 & - & - & - & 0.67 & 1.0 & - & - & - \\
\hline $\mathrm{R}$ & 500 & 0.67 & 1.8 & 1.1 & - & - & 0.68 & 3.3 & 2.0 & - & - \\
\hline
\end{tabular}




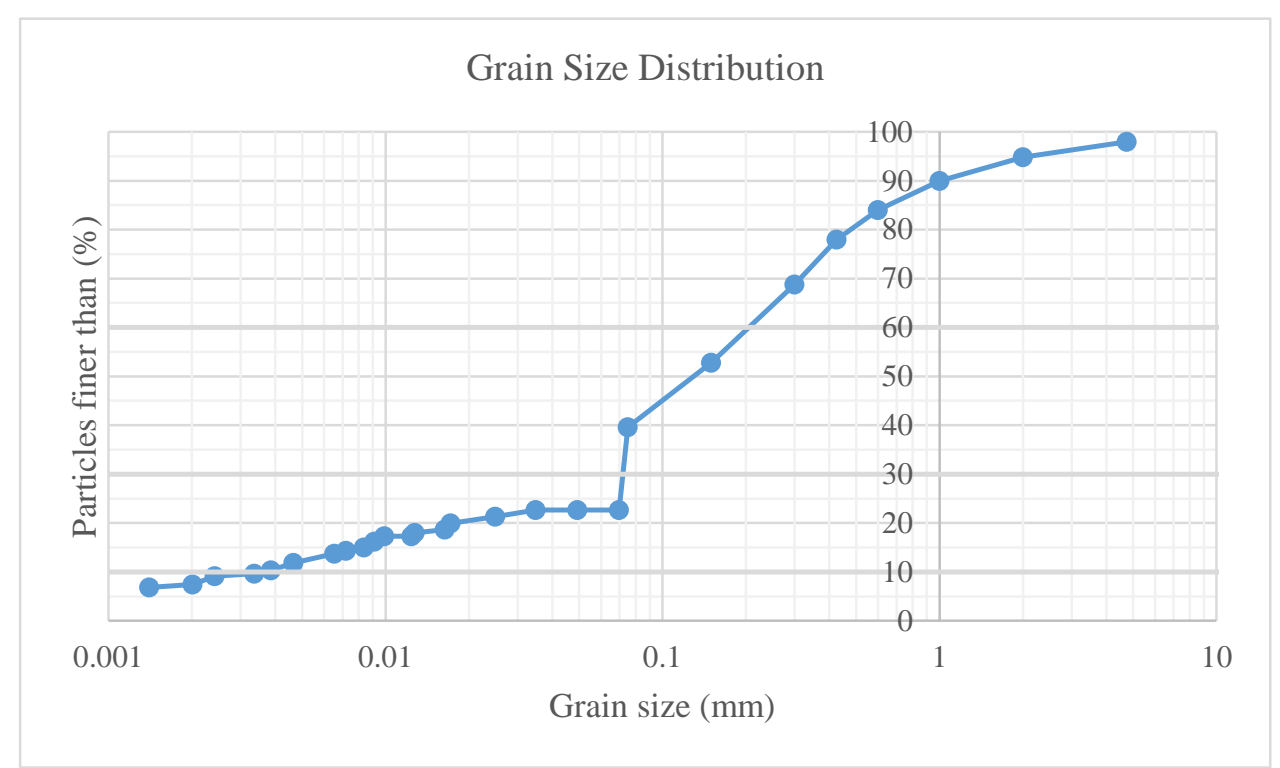

Fig. 1. Grain size distribution curve for soil sample from Location 1

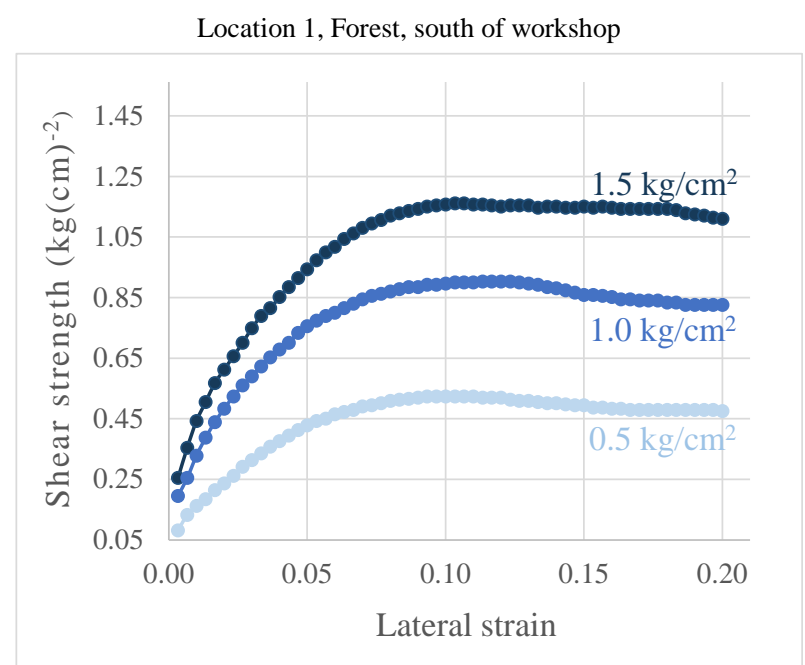

UU Direct Shear Test

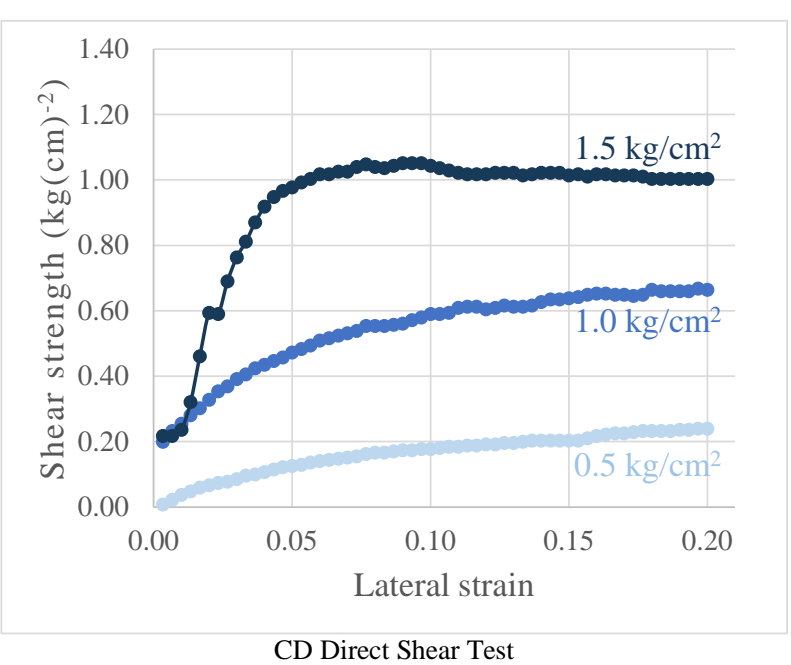

CD Direct Shear Test

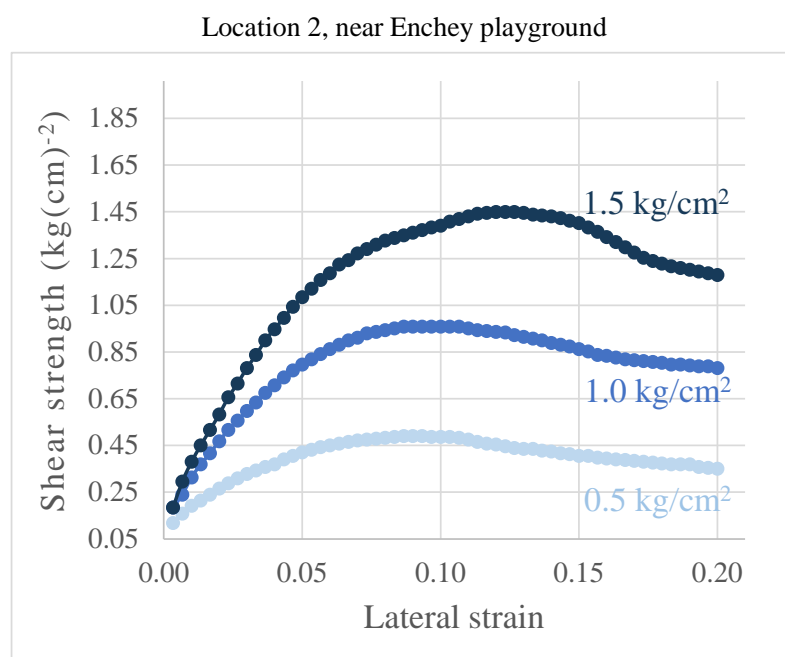

UU Direct Shear Test

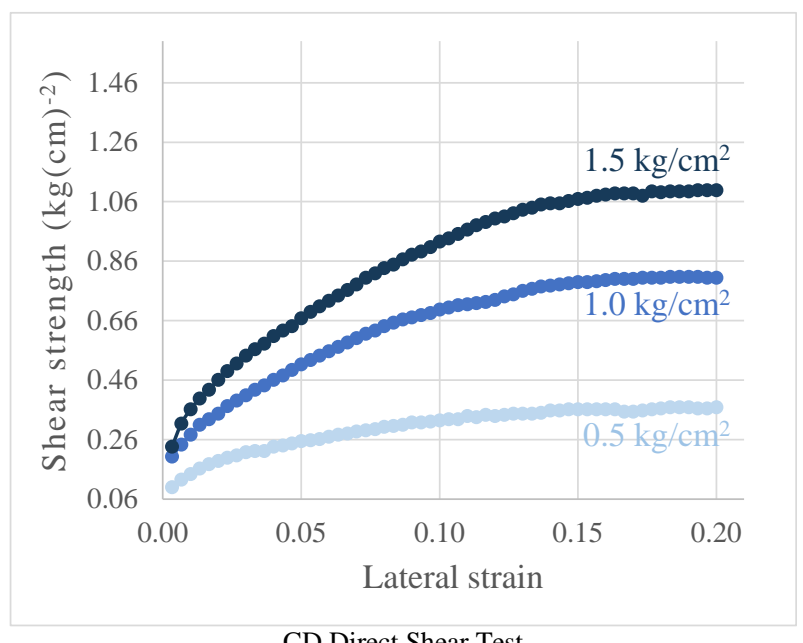

CD Direct Shear Test

Fig. 2. (a) Stress-strain curves obtained from the direct shear tests 
Location 1, Forest, south of workshop

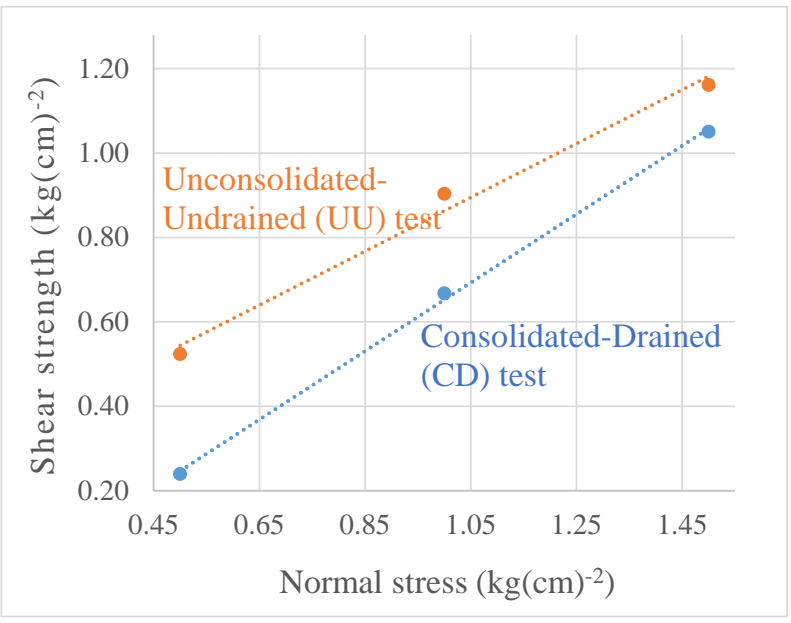

Fig. 2. (b) Plot of shear strength versus normal stress

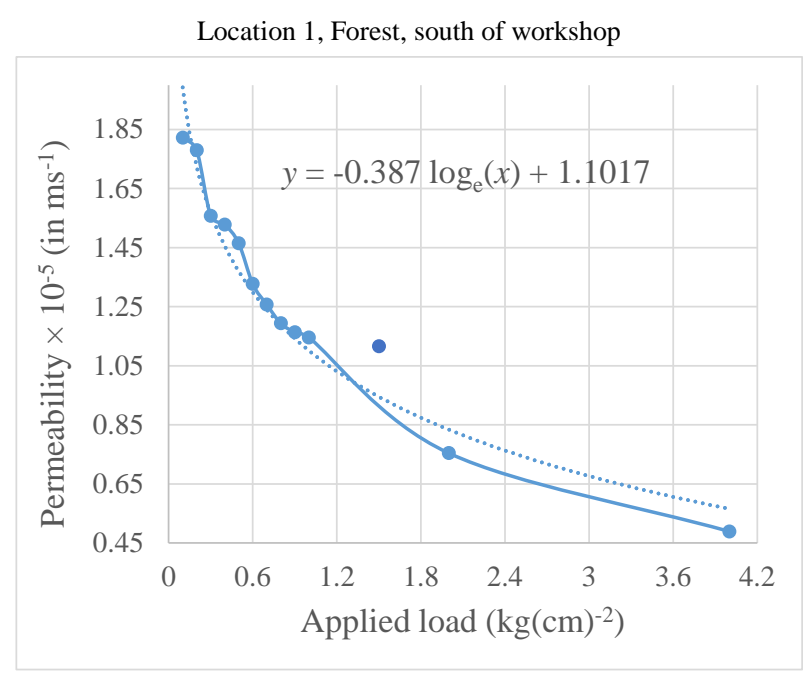

Fig. 3. (a) Permeability versus applied load

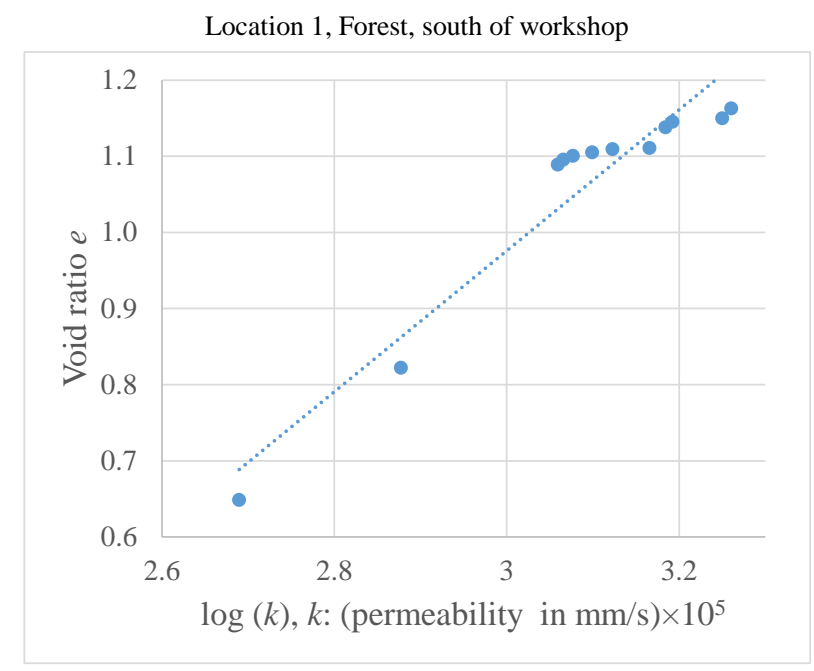

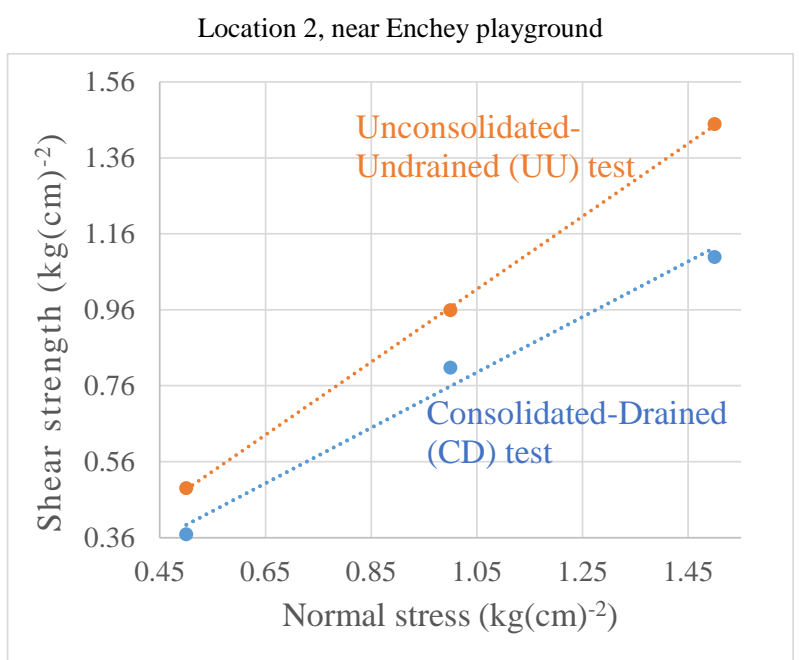
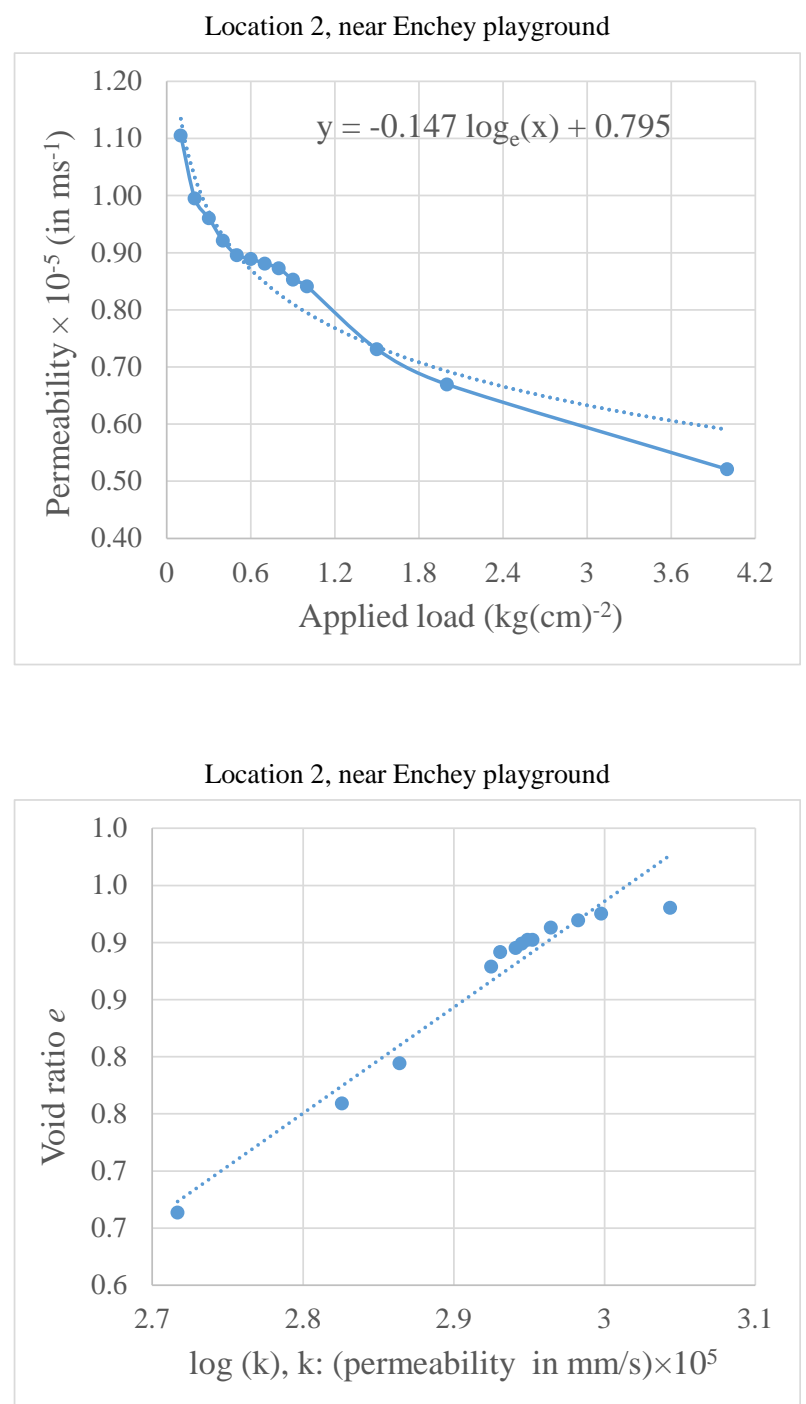

Fig. 3. (b) Void ratio $e$ versus $\log (k)$

The soil and rock properties are used to compute the static factor of safety, as explained later in this paper. 
TABLE II. BORE LOG

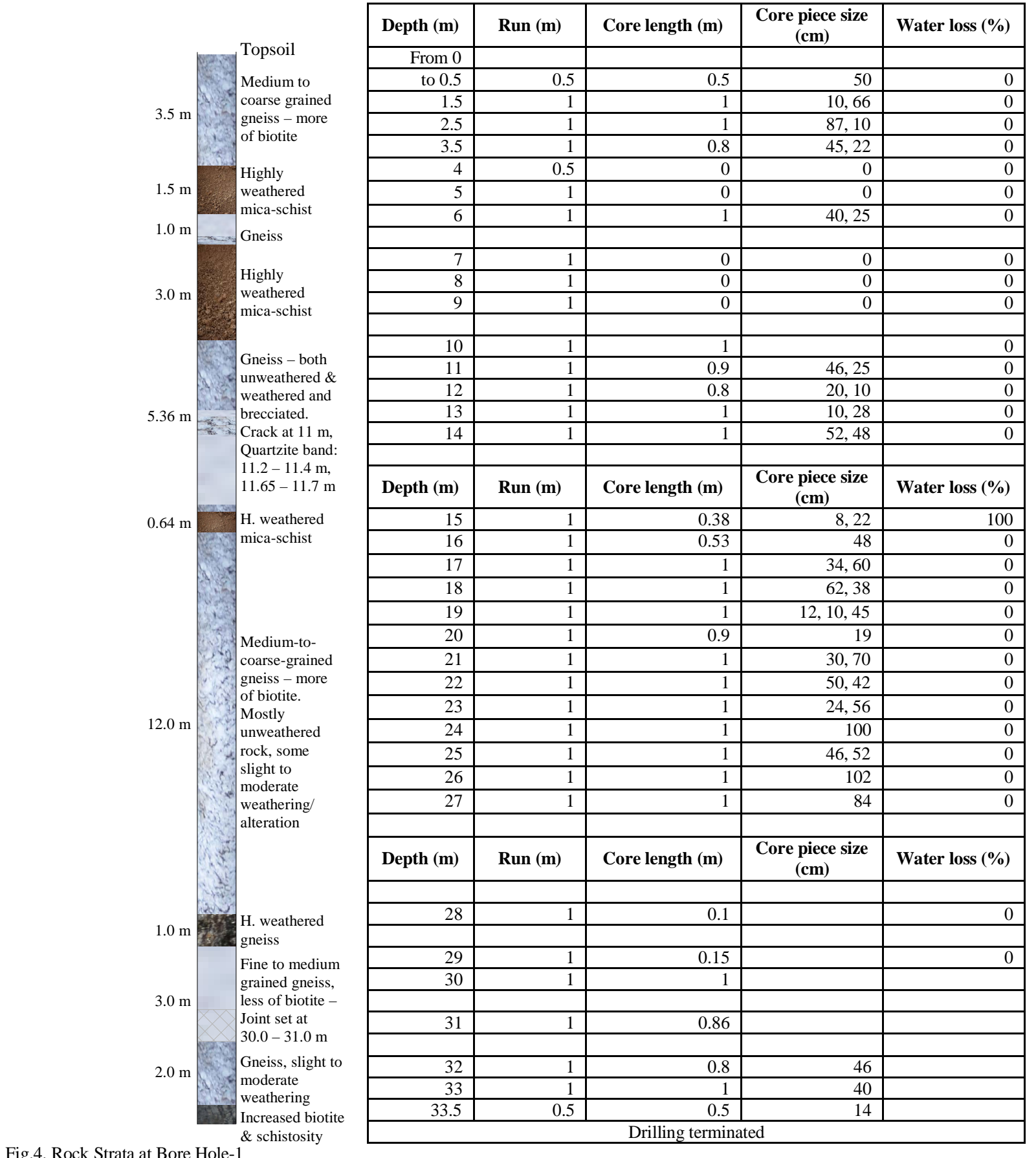

Fig.4. Rock Strata at Bore Hole-1

\section{Rock Tests}

\section{1) Intact gneissic rock}

TABLE III. PROPERTIES OF GNEISSIC ROCK SAMPLES FROM BOREHOLE 1

\begin{tabular}{|l|c|l|}
\hline Property & Value & Sample used for the test \\
\hline Bulk weight $\left(\mathrm{kN} / \mathrm{m}^{3}\right)$ & 25.5 & $\begin{array}{l}\text { Average of } 96 \text { samples } \\
\text { from } 0.0-33.5 \mathrm{~m}\end{array}$ \\
\hline $\begin{array}{l}\text { Point load index [13] - } \\
\text { Compressive strength }(\mathrm{MPa})\end{array}$ & 54 & $\begin{array}{l}\text { Sample from an approx. } \\
\text { depth of } 13.7-13.76 \mathrm{~m}\end{array}$ \\
\hline $\begin{array}{l}\text { Tensile strength }(\mathrm{MPa}) \\
\text { (loading rate: } 0.46 \mathrm{kN} / \mathrm{min})\end{array}$ & 2.0 & $\begin{array}{l}\text { Sample from an approx. } \\
\text { depth of } 5.27-5.39 \mathrm{~m}\end{array}$ \\
\hline
\end{tabular}

TABLE IV. RESUltS OF UNIAXIAL COMPRESSIVE STRENGTH TEST

\begin{tabular}{|l|l|l|l|l|}
\hline & Depth (m) & $\begin{array}{l}\text { Compressive } \\
\text { Strength } \\
\text { (MPa) }\end{array}$ & $\begin{array}{l}\text { Young's } \\
\text { Modulus } \\
\text { (GPa) }\end{array}$ & $\begin{array}{l}\text { Poisson's } \\
\text { Ratio }\end{array}$ \\
\hline 1 & $5.39-5.49$ & 48.7 & 13.9 & 0.53 \\
\hline 2 & $12.7-12.78$ & 68.5 & & \\
\hline 3 & $13.5-13.58$ & 61.5 & & \\
\hline 4 & $13.74-13.87$ & 63.6 & & \\
\hline
\end{tabular}


${ }^{1}$ Tables III and IV: The column specifies the approximate depths from which the rock samples were extracted in Borehole 1 (Fig. 4).

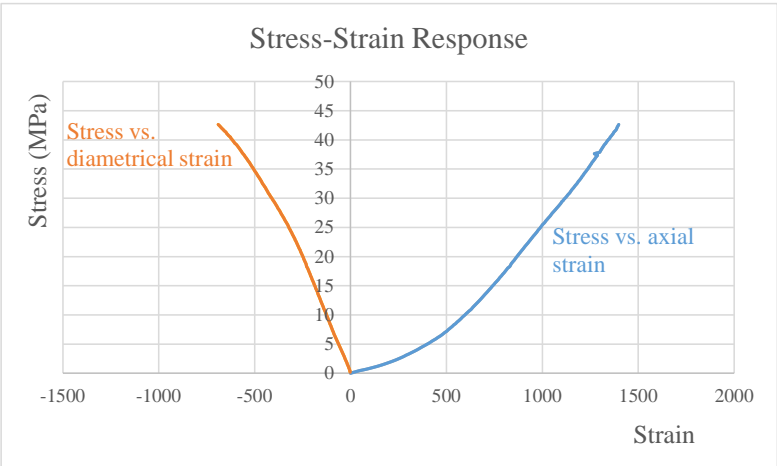

Fig. 5. Stress-strain response of gneissic rock under uniaxial compression (Sample 1, results provided in Row 1, Table IV).

\section{2) Weathered (mica-schist) rock}

As mentioned earlier in this paper, samples obtained from depths of $3.5-5.0 \mathrm{~m}, 6.0-9.0 \mathrm{~m}$, and $14.36-15.0 \mathrm{~m}$ were weathered to the size of fine sand. We performed dry sieve analysis and the consolidated drained direct shear tests on sample from a depth of $3.5-5.0 \mathrm{~m}$ to obtain the grain size distribution and shear strength parameters, respectively.

TABLE V. GRAin Size Distribution OF WEATHERED RoCK (3.5 - 5.0 M)

\begin{tabular}{|l|l|r|}
\hline Grain size & $\begin{array}{l}\text { Diameter limits, Indian Standard } \\
\text { classification IS 2720 (Part 4) }\end{array}$ & $\begin{array}{l}\text { Percentage in } \\
\text { weathered rock }\end{array}$ \\
\hline Gravel & $>4.75 \mathrm{~mm}$ & 0.0 \\
\hline Coarse sand & $4.75 \mathrm{~mm}-2 \mathrm{~mm}$ & 23.04 \\
\hline Medium sand & $2 \mathrm{~mm}-425 \mu \mathrm{m}$ & 67.71 \\
\hline Fine sand & $425 \mu \mathrm{m}-75 \mu \mathrm{m}$ & 7.29 \\
\hline Silt and clay & $<75 \mu \mathrm{m}$ &
\end{tabular}
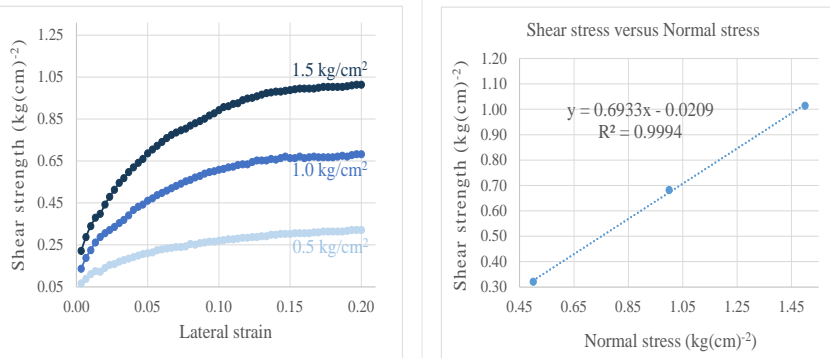

Fig. 6 Results of CD direct shear test on weathered rock (3.5 - 5.0 m depth)

Cohesion: $0 \mathrm{~Pa}$, Angle of internal friction: $34.7^{\circ}$.

\section{SEISMIC HAZARD ESTIMATION}

An updated probabilistic seismic hazard map of Sikkim and the surrounding regions $\left(26^{\circ}-29^{\circ} \mathrm{N}, 87^{\circ}-90^{\circ} \mathrm{E}\right)$ was prepared, incorporating recent findings on the seismicity and seismotectonics of the region. Two types of seismic source models, the linear model and the gridded seismicity model, and three sets of ground motion prediction equations (GMPEs) were considered, and the results obtained from these methods were combined in a logic tree framework. Further details are provided in the following subsections.

\section{A. Seismic Source Models}

\section{1) Linear sources}

The Seismotectonic Atlas (SEISAT, 2000), published by the Geological Survey of India (GSI), is one of the most comprehensive documents listing linear seismic sources in India and its adjoining areas. The map was prepared after extensive research using remote sensing techniques and was further verified by geological explorations. The details of the faults, lineaments, shear zones, and geological features in India and the adjoining areas are presented in SEISAT.

We scanned and georeferenced the sheets of SEISAT, and merged individual images to form the complete map of India. Georeferencing and digitization of the seismotectonic maps were performed using MapInfo Professional 6.0. Declustered earthquake data were superimposed on the fault map and the maximum reported magnitude along each of these sources was noted. Two different maximum magnitudes were considered for linear sources: the maximum historical magnitude $M_{\max }$, and $M_{\max }+0.5$. $M_{\max }$ was identified for each fault in the region.

\section{2) Gridded seismicity model}

The gridded seismicity model is based on the seismic activity rate obtained from earthquake catalogues, and is one of the most widely adopted methods to model seismic sources for regions where there aren't clearly identified seismic sources [14], [15]. In the present case, the study area was divided into grids of size $0.02^{\circ} \times 0.02^{\circ}$ (approximately 2 $\mathrm{km} \times 2 \mathrm{~km}$ ). In each grid, the number of earthquakes which had magnitudes higher than a cutoff magnitude was counted. This gave the activity rate for that particular grid cell. In the present study, the cutoff magnitude $\left(\mathrm{M}_{\text {cut }}\right)$ was selected as $\mathrm{M}_{\mathrm{w}}=4.0$. Based on this value, the recurrence rates for different magnitude intervals were calculated, and these values were smoothed using a Gaussian function to get the final activity rate for each grid cell (Eq. 1). The uncertainties involved in estimating the location of an earthquake event and the size of the seismic source were accounted for by this smoothing.

$$
\hat{n}_{i}=\frac{\sum_{j} n_{j} e^{-\Delta_{i j}^{2} / c^{2}}}{\sum_{j} e^{-\Delta_{i j}^{2} / c^{2}}}
$$

$\hat{n}_{i}$ : Smoothed number of earthquakes in the $i^{\text {th }}$ grid cell

$n_{j}$ : Number of earthquakes in the $j^{\text {th }}$ grid cell

$c$ : Correlation distance to account for location uncertainties

$\Delta_{i j}$ : Distance between the $i^{\text {th }}$ and $j^{\text {th }}$ cells

\section{B. Ground Motion Models}

Appropriate GMPEs should be used for different tectonic regions. In India, due to scarcity of strong motion data, there are few region or site-specific GMPEs. In the present study, we used three well-accepted GMPEs developed for different regions of the world: those developed by Sharma et al. [16], Boore and Atkinson [17], 
and Akkar and Bommer [18]. Sharma et al. [16] developed GMPEs for the Himalayan regions of India using data from the Himalayas and the Zagros regions, on the premise that the seismotectonics of the two regions have considerable similarity. Boore and Atkinson [17] developed GMPEs for active tectonic regions across the world, and Akkar and Bommer [18] developed GMPEs for active tectonic regions of Europe and the Middle East. The regions have similar seismic attenuation characteristics as our present study area, accounting for our choice of these three sets of GMPEs.

\section{Logic Tree Structure}

Uncertainties in the models used for seismic hazard assessment make it difficult to select one particular seismic hazard model. This difficulty can be circumvented by the use of a logic tree approach. A logic tree consists of a series of nodes and branches, and these branches denote different models/hypotheses. A subjective weight, based on engineering judgement, can be given to each of these branches. The sum of the weights for all the branches at a particular node should equal unity. The weight of a terminal branch of the logic tree can be obtained by multiplying the weights of all the branches leading to it. Our logic tree is presented in Fig. 7.

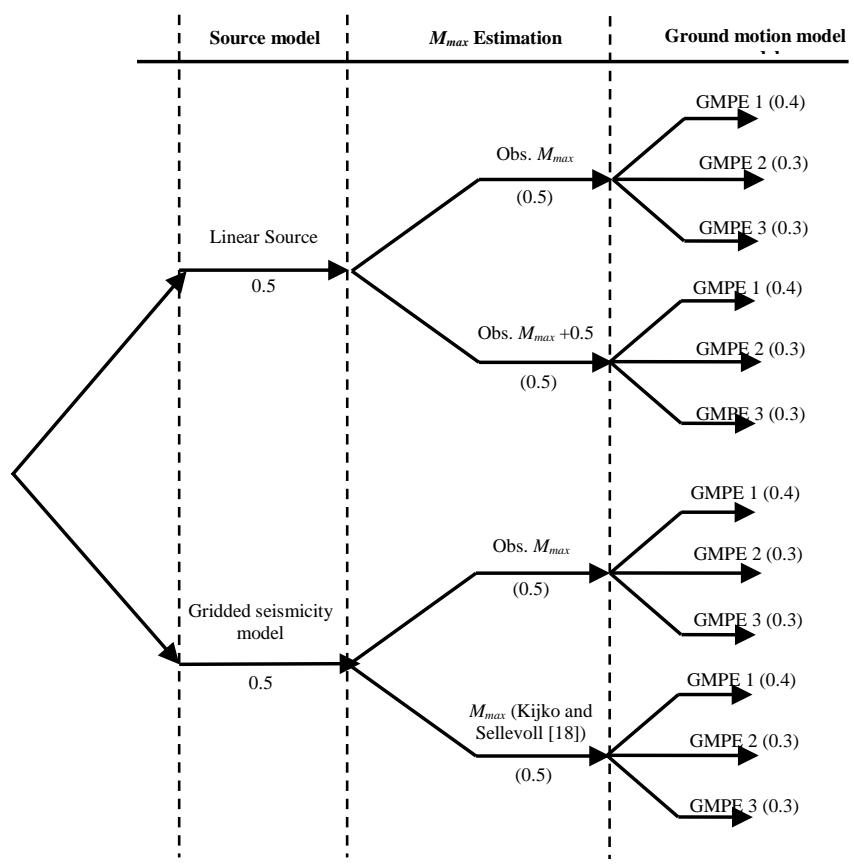

Fig. 7 Parameters and weights adopted in the logic tree

\section{Estimation of Hazard}

The seismic hazard evaluation was based on a state-ofthe-art probabilistic seismic hazard analysis (PSHA), and was performed using the classical Cornell-McGuire approach. Regional seismic source zones were characterized to allow for local variability in seismicity characteristics. The seismicity parameters estimated for regional seismic source zones by Kolathayar and Sitharam [20] were used as inputs in the present hazard analysis. The hazard curves obtained show the variation of peak horizontal acceleration
(PHA) or spectral acceleration (Sa) against mean annual rate of exceedance.

The occurrence of an earthquake in a seismic source is assumed to follow Poisson's Distribution. The probability that a ground motion parameter at a given site, $Z$, will exceed a specified level, $z$, during a specified time, $T$, is represented by the expression:

$$
P(Z>z)=1-e^{-v(z) T} \leq v(z) T
$$

where $v(z)$ is the mean annual rate of exceedance of the ground motion parameter, $Z$, with respect to $z$. The function incorporates the aleatory variability in time, size, and location of future earthquakes, and uncertainties in the ground motion they produce at the site. It is given by:

$$
v(z)=\sum_{n=1}^{N} N_{n}\left(m_{0}\right) \int_{m=m_{e}}^{m_{m}} f_{n}(m)\left[\int_{r=0}^{\infty} f_{n}(r \mid m) P(Z>z \mid m, r) d r\right] d m
$$

$N_{n}\left(m_{0}\right)$ : Frequency of earthquakes on a seismic source $n$, having a magnitude equal to or greater than a minimum magnitude $m_{0}$

$m_{0}=4.0$ in the present study

$f_{n}(m)$ : Probability density function, where $m_{0} \leq m \leq M_{\max }$

$f_{n}(r \mid m)$ : Conditional probability density function (the probability of occurrence of an earthquake of magnitude $m$ at a distance $r$ from the site for a seismic source $n$ )

$P(Z>z \mid m, r)$ : Probability at which the ground motion parameter $Z$ exceeds a predefined value of $z$ when an earthquake of magnitude $m$ occurs at a distance $r$ from the site.

The integral in the expression for $v(z)$ can be replaced by a summation, and the density functions $f_{n}(m)$ and

$f_{n}(r \mid m)$ can be replaced by discrete mass functions. The resulting expression is then given by:

$$
\nu(z)=\sum_{n=1}^{N} \sum_{m_{i}=m_{0}}^{m_{\max }} \lambda_{n}\left(m_{i}\right)\left[\sum_{r_{j}=r_{\min }}^{r_{\max }} P_{n}\left(R=r_{j} \mid m_{i}\right) P\left(Z>z \mid m_{i}, r_{j}\right)\right]
$$

where $\lambda_{n}\left(m_{i}\right)$ is the frequency of an earthquake of magnitude $m_{i}$ at the source $n . \lambda_{n}\left(m_{i}\right)$ is obtained by discretizing the earthquake recurrence relationship for the source $n$.

We performed the seismic hazard analysis by dividing the entire study area into grid cells of size $0.02^{\circ} \times 0.02^{\circ}$ (about $2 \mathrm{~km} \times 2 \mathrm{~km}$ ). For each grid cell, the peak horizontal acceleration value corresponding to a probability of exceedance (PE) of $10 \%$ in 50 years was evaluated at bedrock level. While evaluating the seismic hazard using PSHA method, the hypocentral and magnitude uncertainties were considered. This was done by deaggregating the hypocentral distance into small intervals of $2 \mathrm{~km}$ and the 
magnitude (between minimum and maximum magnitude) into small incremental values of 0.2.

For each grid cell, all sources within a radius of $300 \mathrm{~km}$ were considered for evaluation of PHA and Sa values. For the plate boundary regions where earthquake magnitudes are higher, this distance was increased to $500 \mathrm{~km}$. The PHA value at each grid point was estimated using 16 different methods (various combinations of ground motion prediction equations, source models, and different approaches of $M_{\max }$ estimation) and later combined with the logic tree framework (Fig. 7) to obtain a value of peak ground acceleration.

Fig.8 shows the spatial variation of PGA values (in terms of $g$, acceleration due to gravity) at bedrock level corresponding to a return period of 475 years $(10 \%$ probability of exceedance in 50 years). The PGA obtained at

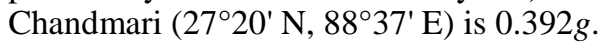

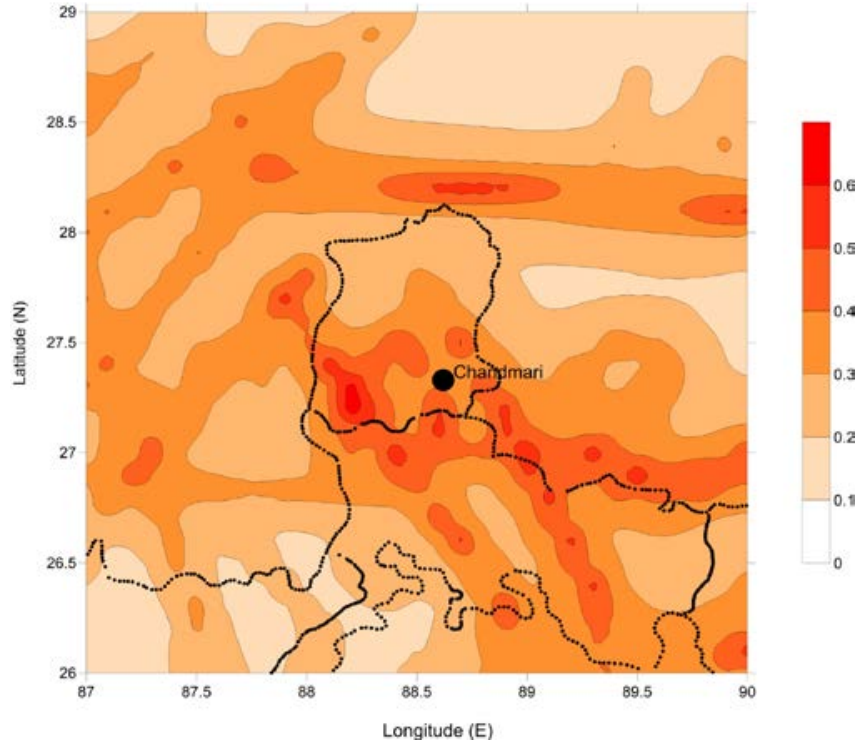

Fig. 8 Spatial variation of PGA values (in terms of $g$ ) at bedrock level, corresponding to a return period of 475 years $(10 \%$ probability of exceedance in 50 years)

\section{A Method For Estimating Seismic LANDSLide HAZARD AT CHANDMARI}

\section{A. Newmark's Sliding Block Analysis}

Newmark's sliding block analysis [21] is a method to calculate the permanent displacement of slopes, dams, and embankments under seismic loading. Newmark modelled the landslide as a rigid block on an inclined plane; the block begins to slide only if the earthquake acceleration $a$ is greater than a critical acceleration $a_{\mathrm{c}}$ needed to overcome shear resistance. The critical acceleration $a_{\mathrm{c}}$ depends on the geometry and the preexisting stability of the slope.

$$
a_{c}=(F S-1) g \sin \alpha
$$

where, FS: static factor of safety, $g$ : acceleration due to gravity, and $\alpha$ : angle between the horizontal and the initial direction of motion of the center of mass of the slide, which can be usually approximated to the slope angle.

\section{B. Static Factor of Safety}

There exist several methods to compute the static factor of safety (the ratio of resisting to driving forces) of the hill slope. Simple methods for soil slopes involve the use of slope stability charts [22], [23], [24]; many of these methods require only the shear strength parameters, bulk density of the soil, and slope angle. Most limit equilibrium methods [23], [25], [26], provide results with reasonable accuracy for soil slopes once the critical slip surface has been correctly identified.

However, discrete element methods are possibly best suited for a realistic modelling of the Chandmari rock and debris slides. These methods can be used to simulate complex landslides where failure occurs in different parts of the slope, and where the failure evolves as it progresses. Moreover, the methods can be used to model both rainfall and earthquake triggered landslides. We are working towards the implementation of discrete element models for the 3-D stability analysis of Chandmari Hill.

We performed the soil and rock tests with a view to obtain all parameters needed to model slope stability and compute the static factor of safety. We measured the hydraulic permeability and consolidation parameters to enable the incorporation of hydrological processes in our slope stability models [27].

\section{Earthquake Acceleration, in terms of $m$ and $r$}

The ground motion prediction equations provide expressions for the peak horizontal acceleration or the spectral acceleration at bedrock level in terms of $m$, the moment magnitude of the earthquake, and $r$, the shortest distance from the site to the earthquake [16]. The PHA or Sa at ground level can be obtained by multiplying the PHA or Sa at bedrock level with suitable amplification factors [28], [29]. We intend to carry out rigorous analyses, similar to that presented in Section $\mathrm{V}$, in order to determine the PHA/Sa, in terms of $m$ and $r$, for our study area. We would again use the most up-to-date information on the seismicity of the region, and combine both linear and gridded seismicity models and several GMPEs in a logic tree framework.

Our study area can be divided into even smaller grids (than in our initial study, described in Section V), and the earthquake acceleration (PHA or Sa) can be computed for every grid cell. Further, the static factor of safety, and hence the critical acceleration (Eq. 3), can also be computed for each grid cell. An estimate of seismic landslide hazard can be obtained by a comparison of the earthquake acceleration with the critical acceleration [30].

\section{CONCLUDING REMARKS}

We presented a thorough analysis, considering different linear and gridded seismicity models and several sets of ground motion prediction equations, to estimate seismic hazard at Chandmari Hill, Gangtok City, Sikkim Himalayas. 
We estimated peak ground acceleration at Chandmari to be $0.392 g$.

Additionally, we presented a detailed report of the Chandmari soil and rock tests. We then described a method that uses both the soil and rock properties of Chandmari and an analysis of the seismotectonics of the region to estimate seismic landslide hazard at Chandmari Hill. This work serves as a basis for a more in-depth study of earthquakeinduced landslides in and around Gangtok City, and possibly even the entire Sikkim Himalayas.

\section{ACKNOWLEDGEMENTS}

We gratefully acknowledge Mr. Dhayalan, Mr. Meganathan, Mr. Sreenivasan, Mr. Chandramohan, Mr. Baladandapani, Mr. Vijayakumar, Mr. Kanagaraj, and Mr. Dhananjay for helping us fabricate equipment and perform various soil and rock tests in their respective laboratories of our university. We thank all the faculty of the Ettimadai Civil Engineering department, and the laboratory staff: Ms. Bindya, Ms. Kavitha, Ms. Radhika, Mr. Vishnuprasad, Mr. Balasundaram, and Ms. Thangamani, for helping us despite their busy schedule.

Amrita University's Landslide Detection Project is a multi-disciplinary one involving scientists and researchers with varied technical expertise. The authors are grateful for contribution from all members of the team. We are especially thankful to Dr. H. M. Iyer and Dr. R. Dhandapani for their technical guidance. Lastly, we would like to sincerely thank our Chancellor, Amma, for constantly motivating us in our work, and reminding us that our work and lives should benefit society.

This work was funded in part by the Ministry of Earth Sciences (MoES), Government of India.

\section{REFERENCES}

[1] D. Petley "Global deaths from landslides in 2010." http://blogs.agu.org/landslideblog/2011/02/05/global-deaths-fromlandslides-in-2010/ 2011.

[2] D. Petley "Global patterns of loss of life from landslides.” Geology, vol. 40, no.10, pp. 927-930, 2012.

[3] D. Kirschbaum "Developing a common methodology and platform for data collection and sharing - Global Landslide Catalogue.” Proc. of the Consultative Workshop on Landslide Inventory, Risk Assessment, and Mitigation in Nepal, 28-29 September 2015, Kathmandu, Nepal, 2015.

[4] D. Petley "Fatal landslides in 2016 so far." http://blogs.agu.org/ landslideblog/2016/05/18/fatal-landslides-in-2016-so-far/ 2016.

[5] D.J. Varnes "Slope movement - types and processes." Landslides: Analysis and Control (Transportation Research Board Special Report 176) Editors: R.L. Schuster and R.J. Krizek, pp 11-33, 1978.

[6] D.M. Cruden and D.J. Varnes "Landslide types and processes" Landslides: Investigation and Mitigation (Transportation Research Board Special Report 247) Editors: A.K. Turner and R.L. Schuster, Published by National Academy Press. chap. 3 pp 36-75, 1996.

[7] M.V. Ramesh and N. Vasudevan. "The deployment of deep-earth sensor probes for landslide detection.” Landslides, vol. 9, no.4, pp. 457-474, 2012.

[8] M.V. Ramesh "Design, development, and deployment of a wireless sensor network for detection of landslides.” Ad Hoc Networks, vol. 13, pp. 2-18, 2014.
[9] Sikkim State Disaster Management Authority SSDMA "Mulithazards risk vulnerability assessment. Gangtok, East Sikkim.” 2012.

[10] K. Bhattacharyya "Geometry and kinematics of the fold-thrust belt and structural evolution of the major Himalayan fault zones in the Darjeeling-Sikkim Himalaya, India.” PhD thesis, University of Rochester, Rochester, USA. 2010.

[11] R. Bhasin, E. Grimstad, J. O. Larsen, A. K. Dhawan, R. Singh, S. K. Verma, K. Venkatachalam "Landslide hazards and mitigation measures at Gangtok, Sikkim Himalaya.” Engineering Geology, vol. 64, no. 4 pp. 351-368, 2002.

[12] K. R. Arora "Soil Mechanics and Foundation Engineering” Delhi: A.K. Jain, 2000.

[13] A Palmström "RMi - a rock mass characterization system for rock engineering purposes.” Ph.D. thesis, Oslo University, Norway, 1995.

[14] A. Frankel "Mapping seismic hazard in the central and eastern United States.” Seismological Research Letters vol. 66, no. 4 pp. 8-21, 1995

[15] G Woo "Kernel estimation methods for seismic hazard area source modeling.” Bull. Seismol. Soc. Am. vol. 86, no. 2, 353-362, 1996

[16] M. L. Sharma, J. Douglas, H. Bungum, J Kotadia "Ground-motion prediction equations based on data from the Himalayan and Zagros regions” J of Earthquake Eng, vol. 13, no. 8, pp.1191-1210, 2009

[17] D. M. Boore, G. M. Atkinson "Ground-motion prediction equations for the average horizontal component of PGA, PGV, and 5\%-Damped PSA at spectral periods between 0.01s and 10.0s" Earthquake Spectra, vol. 24, no. 1, pp. 99-138, 2008

[18] S. Akkar, J. J. Bommer "Empirical equations for the prediction of PGA, PGV, and spectral accelerations in Europe, the Mediterranean Region, and the Middle East.” Seismological Research Letters, vol. 81, no. 2, pp. 195-206, 2010

[19] A. Kijko, M. A. Sellevoll "Estimation of earthquake hazard parameters from incomplete data files. Part I. Utilization of extreme and complete catalogs with different threshold magnitudes.” Bull. Seismol. Soc. Am. vol. 79, no. 3, pp. 645-654, 1989

[20] S Kolathayar, T. G. Sitharam "Characterization of regional seismic source zones in and around India.” Seismological Research Letters, vol. 83, no. 1, pp. 77-85, 2012

[21] N. M. Newmark "Effects of earthquakes on dams and embankments." Geotechnique. vol. 15, no. 2 pp.139-160, 1965

[22] J. M. Duncan, A. L. Buchignani, M. De Wet “An engineering manual for slope stability studies." Department of Civil Engineering, University of California, Berkeley, 1975.

[23] N. Janbu "Slope Stability Computations. Soil Mechanics and Foundation Engineering Report.” Technical University of Norway, Trondheim, 1968

[24] J. H. Hunter, R. L. Schuster "Stability of simple cuttings in normally consolidated clays.” Geotechnique, vol. 18, no. 3, pp. 372-378, 1968

[25] N. R. Morgenstern, V. E. Price “The analysis of the stability of general slip surfaces.” Geotechnique, vol. 15, no. 1, pp. 79-93, 1965

[26] E. Spencer "A method of analysis of the stability of embankments assuming parallel interslice forces.” Geotechnique, vol. 17, no. 1, pp. 11-26, 1967

[27] R. M. Iverson "Landslide triggering by rain infiltration.” Water Resources Research vol. 36, no. 7, pp. 1897-1910, 2000

[28] S. R. Kanth, R. N. Iyengar "Estimation of seismic spectral acceleration in peninsular India.” Journal of Earth System Science. vol. 116, no. 3 pp.199-214, 2007

[29] N. James, T. G. Sitharam "Macro-Level Assessment of Seismically Induced Landslide Hazard for the State of Sikkim, India Based On GIS Technique.” In: IOP Conference Series: Earth and Environmental Science vol. 26, no. 1 pp. 012027, 2015

[30] R. W. Jibson, E. L. Harp, J. A. Michael. “A method for producing digital probabilistic seismic landslide hazard maps.” Engineering Geology vol. 58, no. 3 pp. 271-289, 2000 